\title{
3, 3', 5-triiodo-L-thyronine increases in vitro chondrogenesis of mesenchymal stem cells from human umbilical cord stroma through SRC2
}

\author{
Pablo Fernández-Pernas, ${ }^{1}$ Juan Fafián-Labora, ${ }^{1}$ Iván Lesende-Rodríguez, ${ }^{1}$ Jesús \\ Mateos, ${ }^{2}$ Alexandre De la Fuente, ${ }^{1}$ Isaac Fuentes, ${ }^{1}$ Javier De Toro Santos, ${ }^{1}$ Fco. \\ Blanco García, ${ }^{2}$ and María C. Arufe ${ }^{1}$
}

${ }^{I}$ Grupo de Terapia Celular y Medicina Regenerativa (TCMR-CHUAC), CIBER-BBN/ISCIII, Servicio de Reumatología, Instituto de Investigación Biomédica de A Coruña (INIBIC), Complexo Hospitalario Universitario de A Coruña (CHUAC), SERGAS, Departamento de Medicina, Facultade de Oza, Universidade da Coruña (UDC), As Xubias 15006, A Coruña, Spain

${ }^{2}$ Grupo de Proteómica-PBR2-ProteoRed/ISCIII-Servicio de Reumatologia, Instituto de Investigación Biomédica de A Coruña (INIBIC), Complexo Hospitalario Universitario de A Coruña (CHUAC), SERGAS, Universidade da Coruña (UDC), As Xubias 15006, A Coruña, España

\begin{abstract}
Our group focuses on the study of mesenchymal stem cells (MSCs) from human umbilical cord stroma or Warthońs jelly and their directed differentiation toward chondrocyte-like cells capable of regenerating damaged cartilage when transplanted into an injured joint. This study aimed to determine whether lactogenic hormone prolactin (PRL) or 3, 3', 5-triiodo-L-thyronine (T3), the active thyroid hormone, modulates chondrogenesis in our in vitro model of directed chondrogenic differentiation, and whether Wnt signalling is involved in this modulation. MSCs from human umbilical cord stroma underwent directed differentiation toward chondrocyte-like cells by spheroid formation. The addition of T3 to the chondrogenic medium increased the expression of genes linked to chondrogenesis like collagen type 2 , integrin alpha 10 beta 1 , and Sox9 measured by quantitative real time polymerase chain reaction (qRT-PCR) analysis. Levels of collagen type 2 and aggrecane analyzed by immunohistochemistry, and staining by Safranin O were increased after 14 days in spheroid culture with T3 compared to those without T3 or only with PRL. B-catenin, Frizzled, and GSK-3 $\beta$ gene expressions were significantly higher in spheroids cultured with chondrogenic medium $(\mathrm{CM})$ plus T3 compared to CM alone after 14 days in culture. The increase of chondrogenic differentiation was inhibited when the cells were treated with T3 plus ML151, an inhibitor of the T3 steroid receptor. This work demonstrates, for first time, that T3 promotes differentiation towards chondrocytes-like cells in our in vitro model, that this differentiation is mediated by steroid receptor co-activator 2 (SRC2) and does not induce hypertrophy.
\end{abstract}

KEY WORDS: Mesenchymal stem cells; Human umbilical cord stroma; Chondrocyte-like cells; Chondrogenesis; prolactin; 3, 3', 5-triiodo-L-thyronine 
The umbilical cord stroma or Warthońs jelly, is a promising source of mesenchymal stem cells (MSCs) [Arufe et al., 2011a; Subramanian et al., 2015]. The umbilical cord is a disposable tissue and there are no limitations for obtaining umbilical cords from the maternity facilities in hospitals. MSCs can be differentiated towards any mesoderm lineage [Arufe et al., 2011b] and also some ectodermic lineages, such as neural progenitors [Park et al., 2012]. The chondrogenic differentiation of MSCs has been achieved by our group by the use of a defined medium, but the levels of aggrecan, the major proteoglycan involved in the composition of the extracellular matrix of articular cartilage, did not occur homogeneously [Arufe et al., 2011a; De la Fuente et al., 2012]. Lactogenic hormone prolactin (PRL), the product of a single gene synthesized by the pituitary and many extra-pituitary tissues, modulates growth, and chondrogenic differentiation of human bone marrow-derived MSCs [Ogueta et al., 2002]. Several investigators have focused their studies on the chondro-regulatory role of PRL on the tibial growth plate of lactating rats [Suntornsaratoon et al., 2010a,2010b,2010c]. It has been established that osteoblasts are a target for PRL in the production of new bone formation [Clément-Lacroix et al., 1999] but until now its role into chondrogenesis is not clear. Integrin alpha 10 beta 1 (ITGa10) is a protein expressed by chondrocytes in hyaline cartilage joint and it is the dominating collagen-binding during cartilage development [Camper et al., 2001; Freyria et al., 2009]. Expression of ITGa10 is initiated at the beginning of chondrogenesis and continues throughout cartilage development in adult cartilage and transcription factor activating enhancer-binding protein epsilon (AP-2 $\epsilon$ ) is involved in the regulation of their transcription in chondrocytes [Wenke et al., 2006]. Transcription factor activating enhancer-binding protein alpha (AP-2 $\alpha)$ is expressed in the growth plate and in articular cartilage, and has been described as a negative regulator of chondrocyte differentiation [Huang et al., 2004]. We check the expression of all these transcription factors during our study to validate our in vitro chondrogenic model. Several studies show that T3 activates Wnt-4 expression and Wnt/beta-catenin signalling in rat growth plate chondrocytes [Wang et al., 2007]. Wnt antagonists, Frzb/sFRP3 and Dkk1, inhibit T3-induced Wnt/beta-catenin activation and inhibit the maturationpromoting effects of T3 in growth plate cells. The study by Wang et al. [2007] indicates that thyroid hormone regulates terminal differentiation of growth plate chondrocytes, in part through modulating Wnt/beta-catenin signalling. This study treats to clarify the role what are playing the hormones during chondrogenesis and more concretely the mechanism of T3 action in our model which has not been clarified yet, so we have designed our study to examine this question focused on SRC2. The SRCs are a family of co-regulators whose interaction with thyroid receptor- $\beta$ (TR $\beta$ ) have been extensively studied using non-quantitative methods [Darimont et al., 1998; Moore et al., 2004]. Our study also analyzes the role of SRC2, a steroid co-receptor of T3, in the chondrogenic differentiation process, as well as the role of Wnt signalling during chondrogenesis when T3 was added. 


\title{
MATERIALS AND METHODS
}

\author{
TISSUE COLLECTION
}

Human umbilical cords were obtained from caesarean deliveries of ten healthy women in the Maternity Facility at Complejo Hospitalario Universitario A Coruña (CHUAC). The women were between 26 and 35 years-old. All tissues were obtained with fully informed consent and ethical approval under the supervisor of CEIC of Galicia (Ethical Committee of Galicia).

\section{ISOLATION, CULTURE, AND CHARACTERIZATION OF CELLS}

MSCs were isolated from umbilical cord stroma tissue using an established protocol [Arufe et al., 2011b]. Briefly, the Warthońs jelly tissue was washed with PBS and cut in small pieces, incubated three times for $5 \mathrm{~min}$ with an enzymatic cocktail (1,2 Units/ml dispase and $112 \mathrm{Units} / \mathrm{ml}$ type I collagenase) and cultured to form explants adhering to plastic plate. After three days, the explants were removed, leaving only MSCs attached to the plastic surface. Monolayer cultures of these MSCs were cultured in Dulbeccós Modified Eagles Medium (DMEM), 10\% fetal bovine serum (FBS), $1 \%$ penicillin, and $1 \%$ streptomycin (all from Sigma-Aldrich, Madrid, SP). When the cells achieved $90 \%$ confluence, they were characterized by flow cytometry for mesenchymal stem cells markers: CD90, CD73, CD105; hematopoietic progenitors: CD34, CD45, and endothelial marker: VEGF. After that they underwent directed differentiation towards chondrocyte-like cells.

\section{FLOW CYTOMETRY ANALYSIS}

Cells were washed with PBS twice then pre-blocked with $3 \%$ bovine serum albumin (BSA), or $2-5 \%$ serum from the same species, in PBS. The following direct antibodies were used: phycoerythrin (PE) mouse anti-human CD34 (1:20 from DakoCytomation, Barcelona, SP); FITC mouse anti-human CD45 (1:20 BD Pharmingen, Madrid, SP); FITC mouse anti-human CD105: (1:100 from Serotec, Bavaria, Germany): PE-Cy5.5-conjugated mouse anti-human CD90 (1:20 from BD Pharmingen); PE-conjugated anti-human CD73 (1:20 from BD Pharmingen); and rabbit anti-human VEGF (1:20 from DakoCytomation). For detection of primary antibodies not directly labelled, the cells were washed with PBS, then incubated with polyclonal rabbit anti-mouse IgD/FITC Rabbit F(ab́) 2 (1:1,000 from DakoCytomation) for 30 min at room temperature. The stained cells were then washed twice with PBS and $1 \times 10^{5}$ cells were analyzed with a FACSAria flow cytometer (BD Bioscience, Madrid, SP). FACS data were generated by DIVA software (BD Bioscience). Negative control staining was performed using FITC-conjugated mouse IgG1k isotype, PE-conjugated mouse IgG1k isotype and PE-Cy5.5-conjugated mouse IgG1k isotype (all from BD Pharmingen).

\section{CHONDROGENIC DIFFERENTIATION}

MSCs were seeded in 96-well plates (Sarsted Inc., Barcelona, SP) at $2 \times 10^{4}$ cells per well in growth medium [(DMEM, $10 \%$ FBS, $1 \%$ penicillin, $1 \%$ streptomycin, $1.5 \times 10^{-4} \mathrm{M}$ monothioglycerol (MTG), $5 \mathrm{mg} / \mathrm{ml}$ ascorbic acid (AA), $6 \mu \mathrm{g} / \mathrm{ml}$ transferrin (TRANS) (all from Sigma-Aldrich)] to achieve spontaneous spheroid formation. The medium was then changed to a chondrogenic medium (CM) to direct differentiation towards chondrocyte-like cells and was used as the control medium for all experiments. The CM consisted of DMEM, 15\% knockout serum (GIBCO, Invitrogen, Madrid, SP), and $5 \mathrm{mg} / \mathrm{ml} \mathrm{AA}, 6 \mu \mathrm{g} / \mathrm{ml}$ TRANS, $10 \mu \mathrm{M}$ dexamethasone (DEX), $1 \times 10^{-7} \mathrm{M}$ retinoic acid (all from Sigma-Aldrich), and $10 \mathrm{ng} / \mathrm{ml}$ recombinant human transforming growth factor-beta 3 (TGF- $\beta 3$ ) or $10 \mathrm{ng} / \mathrm{ml}$ TGF- $\beta 3$ plus 1,10 , or $100 \mathrm{ng} / \mathrm{ml}$ of T3 
(both from Sigma-Aldrich) or $10 \mathrm{ng} / \mathrm{ml}$ TGF- $\beta 3$ plus 10,100 , or $1,000 \mathrm{ng} / \mathrm{ml}$ of PRL (from Sigma-Aldrich). In addition, several amounts $(2.5,10$, or $20 \mu \mathrm{M})$ of ML151 (Enamine Ltd, Kiev, Ukraine), an inhibitor of the T3 steroid receptor, alone or with $100 \mathrm{ng} / \mathrm{ml}$ of T3, were tested. The last $200 \mathrm{ng} / \mathrm{ml}$ of recombinant human Dickkopf protein family, DKK-1 (Prepotech, London, UK), was added to the medium alone or into combination with T3. The medium was changed every 3 days. The spheroids formed were collected, frozen, and stored at $4^{\circ} \mathrm{C}$ after 14 days in culture for later analysis.

\section{REAL TIME QUANTITATIVE POLYMERASE CHAIN REACTION (qRT-PCR) ANALYSIS}

Genes codifying for human proteins: collagen type 1 (COL1); collagen type 2, (COL2); collagen type $10(C O L X)$; matrix metalloproteinase-13 (MMP-13); aggrecan (ACAN), alkaline phosphatase $(A L P)$; activator protein 2 alpha $(A P 2 \alpha)$; activator protein 2 epsilon $(A P \epsilon)$, integrin alpha 10 beta 1 (ITGA10) and Sox9 were used to determine the expression of markers for chondrogenic differentiation or hypertrophy in the spheroids performed. All details are shown in Table I. The amplification program consisted of initial denaturation at $92^{\circ} \mathrm{C}$ for $2 \mathrm{~min}$ followed by 40 cycles from $92^{\circ} \mathrm{C}$ for $15 \mathrm{~s}$, annealing at $61^{\circ} \mathrm{C}$ for $30 \mathrm{~s}$, and extension at $72^{\circ} \mathrm{C}$ for $15 \mathrm{~s}$. PCR analyses were done in duplicate, with each set of assays repeated three times. To minimize the effects of unequal quantities of starting RNA and to eliminate potential sources of inconsistency, relative expression levels of each gene were normalized to ribosomal protein (RPLP) or Glyceraldehyde 3-phosphate dehydrogenase (GAPDH) using the $2^{-\Delta \Delta \mathrm{Ct}}$ method [Livak and Schmittgen, 2001]. Control experiments utilized no reverse transcriptase.

Table I. Specific Primers for Real-Time Reverse Transcriptase-Polymerase Chain Reaction (RT-PCR) Amplification, Listed With Their Annealing Temperature (A.T.)

\begin{tabular}{|c|c|c|c|c|}
\hline Gene name & Fw primer & Rv primer & Gene Bank Access & A.T. $\left({ }^{\circ} \mathrm{C}\right)$ \\
\hline COL1A1 $2 f 2 r$ & gtgatgctggtcctgttggt & caccatcgtgagecttctct & NM_000088 & 61 \\
\hline COL2A1 $3 F 3 R$ & gtgtcagggccaggatgt & tcccagtgtcacagacacagat & NM_001844 & 61 \\
\hline COL10A1 & caccttctgcactgctcatc & ggcagcatattctcagatgga & NM_000493 & 61 \\
\hline$R P L P$ & tctacaaccetgaagtgcttgat & caatctgcagacagacactgg & NM_053275 & 61 \\
\hline$M M P-13$ & tttcctcctgggecaaat & gcaqacagaaacaagttgtagcc & NC_000011.10 & 61 \\
\hline$A C A N$ & gcctacgaagcaggctatga & gcacgccataggtcctga & NM_001135.3 & 61 \\
\hline$G S K 3-\beta$ & tcctgcctgctgaagtgaac & tttagctgaggtcttgggcc & NM_001146156.1 & 61 \\
\hline Frizzled-7 & gaggcctgcctgctagaatc & ataaggccaaggagacgtgg & $\mathrm{AB} 017365.1$ & 61 \\
\hline$\beta$-Catenin & cattgtttgtgcagctgcttt & caggacaaggaagctgcaga & NM_001098210.1 & 61 \\
\hline$S R C 2$ & ccagcatccetgtacga & catccacccagcagga & AK301078.1 & 61 \\
\hline$A P 2 \alpha$ & gatcctcgcagggactaca & gttggacttggacagggac & ВC017754.1 & 61 \\
\hline$A P 2 \epsilon$ & gaaatagggacttagctcttgg & ccaagccagatccccaactctg & NM_178548.3 & 61 \\
\hline ITGalo & gtgtggatgcttcattccag & gccatccaagacaatgacaa & NM_003637.3 & 61 \\
\hline Sox 9 & ctccgggacatgatcagc & ggtagtgctgggacatgtgaa & NM_000346.3 & 61 \\
\hline$G A P D H$ & agccacatcgctcagacac & gcccaatacgaccaaatcc & NC_000012.12 & 61 \\
\hline
\end{tabular}

Fw, forward; Rv, reverse. 


\section{PROTEIN ISOLATION AND IMMUNOBLOT ANALYSIS}

Immunoblot analysis was performed on $45 \mu \mathrm{g}$ of total protein extracted from cultured spheroids, as previously described [Matsushime et al., 1994]. The blots were probed with antibodies directed against human glycogen synthase kinase (GSK-3 $\beta$ ), which phosphorylates $\beta$ catenin in the absence of Wnt signal resulting in its ubiquitination and proteosomal degradation; Frizzled-7, a receptor for Wnt; and $\beta$-catenin (all from Santa Cruz Biotechnology, Heidelberg, $\mathrm{GE}$ ); tubulin or GAPDH (both from Sigma-Aldrich) were used for housekeeping. A secondary anti-mouse antibody (Sigma-Aldrich) was used to visualize proteins using an Amersham ${ }^{\mathrm{TM}}$ $\mathrm{ECL}^{\mathrm{TM}}$ Western Blotting Analysis System (GE Healthcare, Amersham Biotechnology, Manchester, UK). Ideal concentrations for each antibody were determined empirically. Working concentrations were 1:1,000 of the recommended stock solutions.

\section{HISTOLOGICAL, IMMUNOHISTOCHEMISTRY, AND IMMUNOFLUORESCENCE ANALYSIS}

Spheroids from MSCs of umbilical cord stroma, following differentiation into chondrocyte-like cells were frozen in OCT embedding matrix (BDH Chemicals, Poole, UK). Full-depth sections $(4 \mu \mathrm{m})$ were cut using a cryostat and fixed in $4 \%(\mathrm{w} / \mathrm{v})$ paraformaldehyde (Sigma-Aldrich) in PBS at $\mathrm{pH}$ 7.6. Some sections were stained with Safranin O (Sigma-Aldrich) to evaluate the distribution of proteoglycan in the spheroid. Other sections were immunostained with monoclonal antibodies against COL1 (1:5,000) (Abcam, Bristol, UK), COL2 (1:200) (Chemicon, Millipore Ibérica S.A, Madrid, SP), COLX (1:1,000) (Sigma-Aldrich), MMP-13 (1:50) (Thermo Scientific, Cienytech, Santiago de Compostela, SP) and ALP (1:200) (R\&D Systems, Millipore Ibérica S.A, Madrid, SP) used as previously described Arufe et al. [2011b]. Biotinylated secondary antibodies were detected using a peroxidase-labelled biotin-streptavidin complex (Vectastain Elite kit; Vector Laboratories, Peterborough, UK) with diaminobenzidine substrate (Vector Laboratories) $(1: 1,000)$. Normal mouse serum was used as a negative control, and the sections were not counterstained. Immunofluorescence analysis was performed by permeabilizing some sections with PBS containing $0.1 \%$ Triton X-100 for 10 min, then pre-blocking with $3 \%$ BSA or $2-5 \%$ serum from the same species in PBS. The antibodies used were human anti- $\beta$-catenin (Santa Cruz Biotechnology) and 4', 6-diamidino-2-phenylindole (DAPI) was used to counter stain the nucleus. Secondary antibody was PE-conjugated anti-mouse (1:1,000 from DakoCytomation).

\section{ELECTRON MICROSCOPY}

Electron microscopic evaluation and immunogold labelling of spheroids followed previously published procedures [Lunstrum et al., 1999]. Briefly, spheroids were fixed by immersion in $1.5 \%$ glutaraldehyde $1.5 \%$ paraformaldehyde containing $0.1 \%$ (w/v) tannic acid, followed by $1 \%$ OsO4. Finally, spheroids were dehydrated, embedded in Spur's epoxy and cut in an ultra microtome. Immunogold labelling was performed on slices from spheroid before fixing. Antibody human antiCOL2 (1:200) (Chemicon, Millipore Ibérica S.A, Madrid, SP) was used followed for incubation with gold conjugate anti-mouse IgG secondary antibody (Sigma-Aldrich). JEOL JEM 1010 transmission electron microscope was used in these experiments.

\section{DENSITOMETRY ANALYSIS}

AnalySIS Image Processing (Soft Imaging system GmbH V. 5.0, Olympus, Münster, Germany) was used to quantify the expression of different antibodies obtained by histochemical analysis shown in the plots. Three fields $200 \mu \mathrm{m}^{2}$ in size from each antibody-COL1, COL2, COLX, MMP-13, ALP-, and Safranin O stain-studied were quantified using arbitrary units for histochemistry values provided by the computer program. Values expressed as percentage of positive cells for each marker studied were used for histochemistry analysis. Control values for 
immunohistochemistry analysis were used from spheroids incubated with the secondary antibody alone.

\section{STATISTICS}

All experiments were performed in triplicate and one representative is shown. Non-parametric statistical analyses were performed by Mann-Whitney- $U$ and Kruskal-Wallis tests using SPSS v 19. A $P$-value less than 0.05 was considered statistically significant. All the the data are presented as standard error of the mean.

\section{RESULTS}

\section{CHARACTERIZATION OF MSCS}

Characterization of MSC populations isolated from human umbilical cord stroma was made using flow cytometry analysis before chondrogenic differentiation studies to determine their percentage of MSCs markers. A high percentage of MSCs were positive for CD73 (>40\%), CD90 $(>80 \%)$, and CD105 (>45\%). The remaining tested markers, VEGF had $<1 \%$ positive cells, with $\mathrm{CD} 34$ and CD45 less than $1 \%$ positive, essentially negative for these markers (Fig. 1A). 
A)

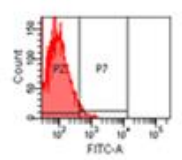

VEGF

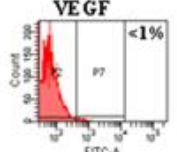

CD105

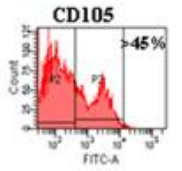

Iso types

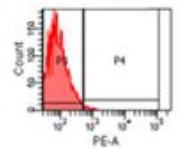

CD34

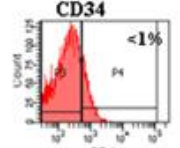

CD73

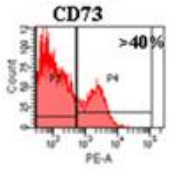

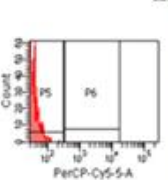
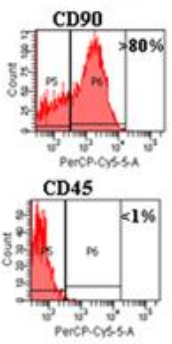

B) $\quad \mathrm{COL} 2$

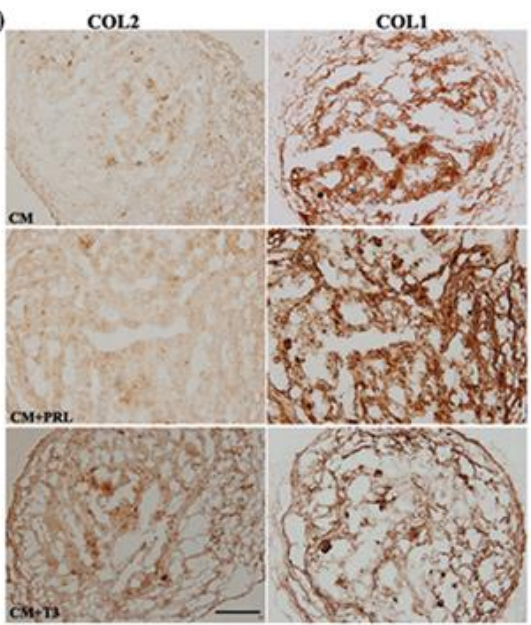

C) COL2/COL1

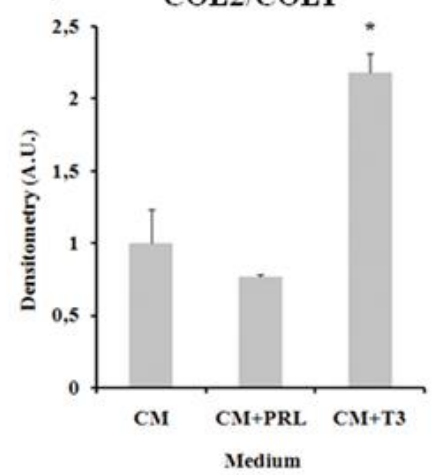

D)
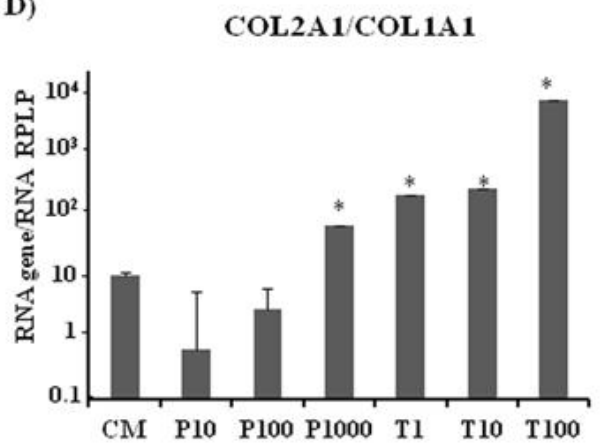

${ }^{*} \boldsymbol{P}<0.05 \mathrm{vs} \mathrm{CM}$

Figure 1. Characterization of mesenchymal stem cells (MSCs) from human umbilical cord stroma and their chondrogenic differentiation through spheroid cultures. (A) Characterization of mesenchymal stem cells population from human umbilical cord stroma by flow cytometry of the surface markers; CD34, CD45, CD73, CD90, CD105, and VEGF. At the top is the name of the marker, at the bottom the fluorochrome used. The percentages of positive cells are indicated at the top right. (B) Representative images of immunohistochemistry tissue sections with antibodies against human collagen type II (COL2) and collagen type I (COL1) protein in spheroids performed with MSCs cultured in chondrogenic medium $(\mathrm{CM})$, or $\mathrm{CM}$ plus $1,000 \mathrm{ng} / \mathrm{ml}$ of prolactin (PRL) $(\mathrm{CM}+\mathrm{PRL})$ or CM plus $100 \mathrm{ng} / \mathrm{ml}$ of 3, 3', 5-triiodo-L-thyronine (T3) $(\mathrm{CM}+\mathrm{T} 3)$. All images have the same magnification (bar $=2 \mathrm{~mm}$ ). (C) Ratios of COL2/COL1 stain protein obtained from densitometry study of slices from spheroids cultured in $\mathrm{CM}+\mathrm{PRL}$ or $\mathrm{CM}+\mathrm{T} 3$ after immunohistochemistry analysis using anti-human COL1 and COL2 antibodies. (D) Real time quantitative reverse transcriptase polymerase chain reaction (qRT-PCR) results: ratio of COL2A1/COL1A1 gene expressions in spheroids performed with MSCs cultured in chondrogenic medium (CM) or CM plus 10, 100, or $1,000 \mathrm{ng} / \mathrm{ml}$ of PRL (P10, P100, and P1,000 respectively) or $\mathrm{CM}$ plus 1,10 , or $100 \mathrm{ng} / \mathrm{ml}$ of T3 (T1, T10, and T100 respectively). RPLP $=60 \mathrm{~S}$ acidic ribosomal protein large $\mathrm{P} 1 . * P<0.05$ versus $\mathrm{CM}$ by Mann-Whitney- $U$ test. 
COL1 and COL2 gene expression dose-response curves were analyzed for PRL at 10, 100, or $1,000 \mathrm{ng} / \mathrm{ml}$ and T3 at 1,10 , or $100 \mathrm{ng} / \mathrm{ml}$ in CM. The dose of $100 \mathrm{ng} / \mathrm{ml}$ of T3 resulted in the most statistically significant $(P<0.05)$ increase of COL2 gene expression compared to CM (Fig. 1B). Densitometry analyses of COL2 and COL1 protein by immunohistochemistry after 14 days in culture were performed using $1,000 \mathrm{ng} / \mathrm{ml}$ of PRL and $100 \mathrm{ng} / \mathrm{ml}$ of T3. The results revealed that the best ratio of COL2/COL1 after 14 days of chondrogenesis was when T3 was added to the medium (Fig. 1C and D). Proteoglycans were more abundant in spheroids cultured with T3 compared with CM or CM plus PRL, as shown by Safranin O staining after 14 days (Fig. 2A) and its densitometry analysis (Fig. 2B), the difference was statistically significant $(P<0.05)$. Corroborating these data, the RT-PCR analysis from $A C A N$ gene was statistically significant highest $(P<0.05)$ in spheroid performed into CM plus $100 \mathrm{mg} / \mathrm{ml}$ of T3 (Fig. 2C). Spheroid cultured during 14 days into chondrogenic medium plus T3 $(100 \mathrm{mg} / \mathrm{ml})$ expressed statistically significant $(P<0.05)$ high levels of $A P-2 \alpha, I T G a 10, C O L 2$, and $A P 2 \epsilon$ genes compared with spheroid cultured during 14 days into $\mathrm{CM}$ alone (Fig. 3A). Spheroid ultra-structure was shown at Figure 3B, there were two MSCs where was possible observe a nucleus also was observed the gap between cells where no structures inside. In the Figure 3C was shown a spheroid cultured into CM after 14 days and COL2 fibers were observed by immune gold staining between cells. In the Figure 3D and E were shown a spheroid cultured into CM plus $100 \mathrm{mg} / \mathrm{ml}$ of T3 after 14 days and COL2 fibers were observed by immune gold staining between cells at different magnifications. 
A)

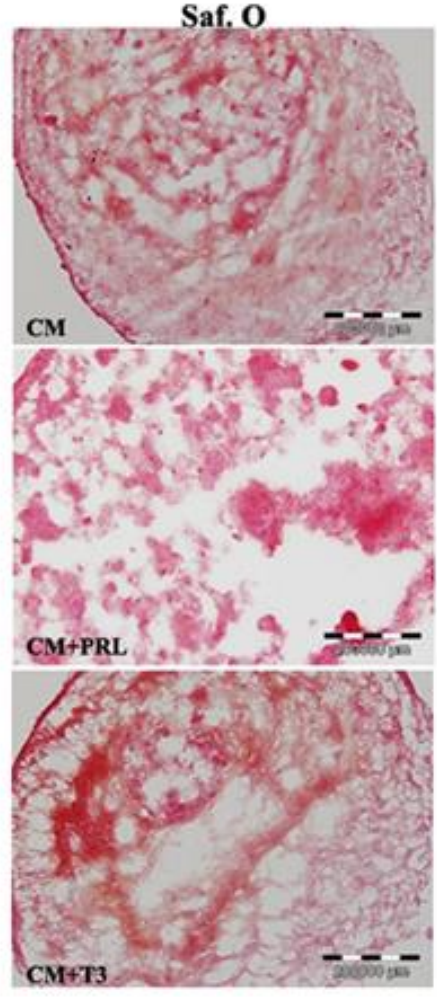

B)

Proteoglycan staining after 14 days in culture

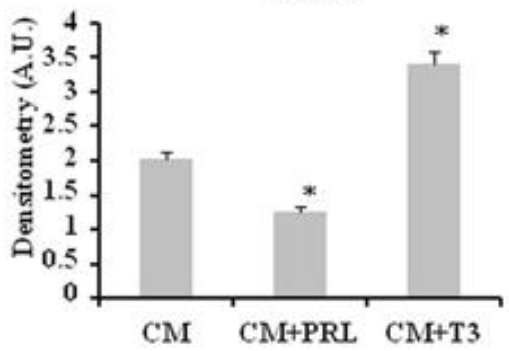

C)

ACAN expression after

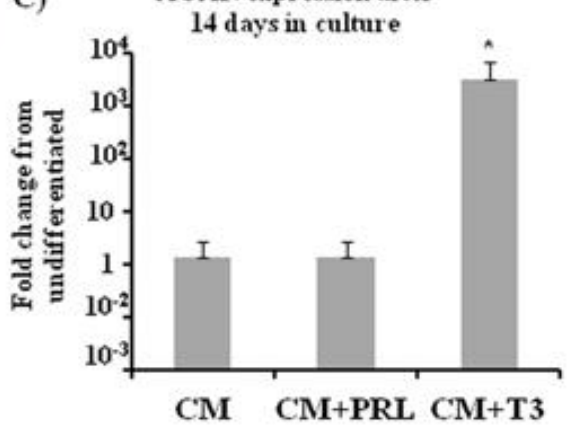

${ }^{*} P<0.05$ v CM

Figure 2. Proteoglycan analyses from spheroid performed by mesenchymal stem cells (MSCs) of human umbilical cord stroma. (A) Representative images of tissue sections of spheroids performed by MSCs stained with Safranin O in chondrogenic medium (CM), CM plus $1,000 \mathrm{ng} / \mathrm{ml}$ of prolactin $(\mathrm{CM}+\mathrm{PRL})$, or $\mathrm{CM}$ plus $100 \mathrm{ng} / \mathrm{ml}$ of 3, 3', 5-triiodo-L-thyronine $(\mathrm{CM}+\mathrm{T} 3)$. All images have the same magnification (bar $=2 \mathrm{~mm}$ ). (B) Densitometry study of proteoglycan staining by Safranin $\mathrm{O}$ (Saf. O) from spheroids performed by MSCs cultured in chondrogenic medium (CM), CM plus $1,000 \mathrm{ng} / \mathrm{ml}$ of prolactin $(\mathrm{CM}+\mathrm{PRL})$, or $\mathrm{CM}$ plus $100 \mathrm{ng} / \mathrm{ml}$ of 3, 3', 5-triiodo-L-thyronine $(\mathrm{CM}+\mathrm{T} 3)$. (C) Real time quantitative reverse transcriptase polymerase chain reaction (qRT-PCR) of $A C A N$ gene in spheroids performed by MSCs cultured in chondrogenic medium (CM), CM plus $1,000 \mathrm{ng} / \mathrm{ml}$ of prolactin $(\mathrm{CM}+\mathrm{PRL})$, or $\mathrm{CM}$ plus $100 \mathrm{ng} / \mathrm{ml}$ of 3, 3', 5-triiodo-L-thyronine $(\mathrm{CM}+\mathrm{T} 3) . * P<0.05$ versus $C M$ by Mann-Whitney- $U$ test. 
A)

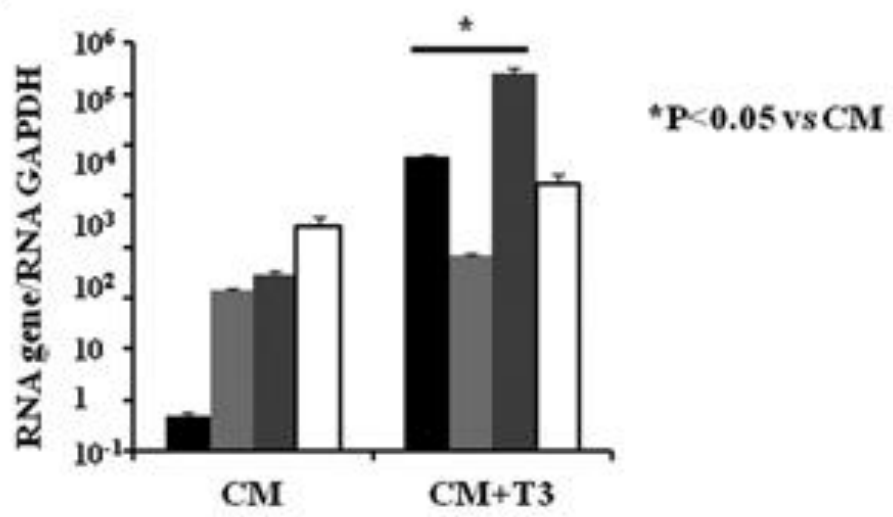

aP2 $\alpha$ ITGa10 $=\mathrm{CoL}$ 口AP2 $\varepsilon$
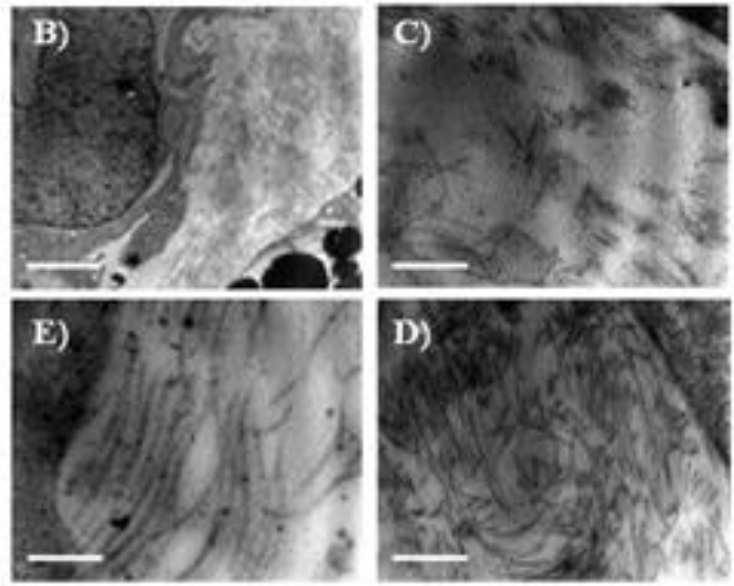

Figure 3. Chondrocyte-like cells study of spheroid performed by mesenchymal stem cell from human umbilical cord stroma. (A) Real time quantitative reverse transcriptase polymerase chain reaction (qRT-PCR) of the $A P-2 \alpha, A p-2 \epsilon, I T G a 10$, and COL2A1 genes in spheroids performed by MSCs cultured in chondrogenic medium (CM) or CM plus $100 \mathrm{ng} / \mathrm{ml}$ of 3, 3', 5-triiodo-L-thyronine $(\mathrm{CM}+\mathrm{T} 3)$. Similar results were obtained from three independent experiments. $* P<0.05$ versus CM by Mann-Whitney- $U$ test. (B) Electron micrograph of a spheroid performed of MSCs from human umbilical cord human stroma after 2 days in chondrogenic medium (CM). Small bar represents $2.5 \mu \mathrm{m}$. (C) Electron micrograph of a spheroid performed of MSCs from human umbilical cord human stroma after 14 days in chondrogenic medium (CM). Small bar represents $2.5 \mu \mathrm{m}$. (D) Electron micrograph of a spheroid performed of MSCs from human umbilical cord human stroma after 14 days in chondrogenic medium plus $100 \mathrm{ng} / \mathrm{ml}$ of 3, 3', 5-triiodo-L-thyronine $(\mathrm{CM}+\mathrm{T} 3)$. Small bar represents $2.5 \mu \mathrm{m}$. (E) Electron micrograph of a spheroid performed of MSCs from human umbilical cord human stroma after 14 days in chondrogenic medium plus $100 \mathrm{ng} / \mathrm{ml}$ of 3, 3', 5-triiodo-Lthyronine $(\mathrm{CM}+\mathrm{T} 3)$. Small bar represents $1 \mu \mathrm{m}$. 
The gene expression of SRC2 was demonstrated using qRT-PCR in MSCs before and after chondrogenic differentiation, so chondrocytes and cartilage from healthy human donors were used as a positive control (Fig. 4A). The chondrogenesis increase produced by T3 in our model of MSCs was inhibited when ML151, a specific inhibitor of SRC2, was added to the medium $1 \mathrm{~h}$ before T3 was added. Three dosages of ML151 $(2.5,10$, and $20 \mu \mathrm{M})$ were assessed in CM alone (Fig. 4B). ML151 at $2.5 \mu \mathrm{M}$ statistically significant reduced $(P<0.05)$ the gene expression ratio of COL2/COL1 in our model, compared to their expression in spheroids cultured with CM plus T3 (Fig. 4C). Immunohistochemistry for COL2 and COL1 protein was also done and corroborated the results of the expression of their respective genes; all dosages of ML151 at $2.5 \mu \mathrm{M}$ significantly reduced $(P<0.05)$ the ratio of staining of COL2/COL1 protein from that of spheroids cultured with CM plus T3 (Fig. 4D and E).

A)

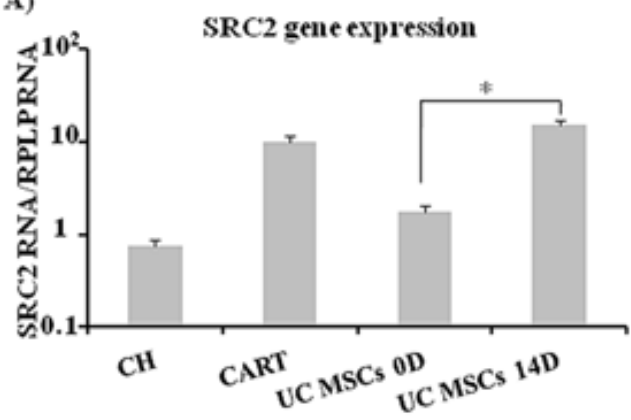

B)

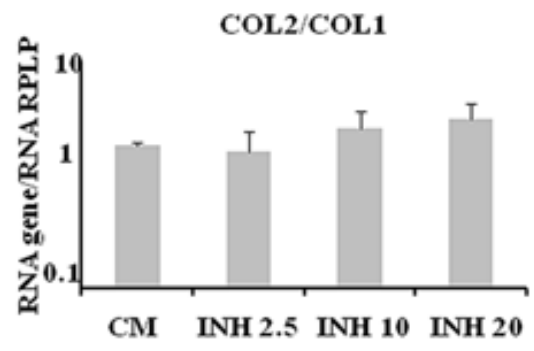

C)

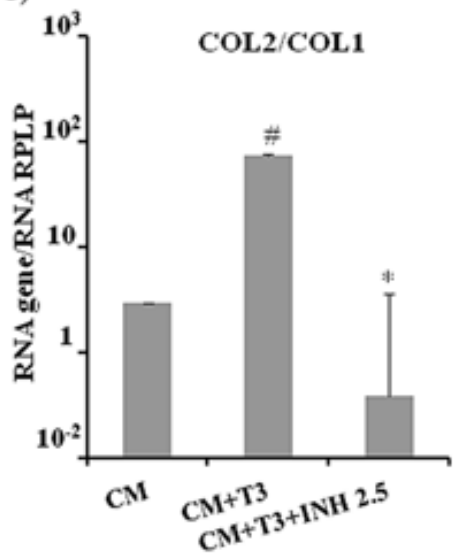

D)

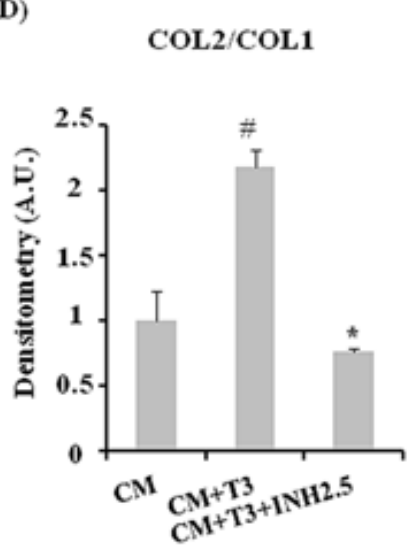

E)

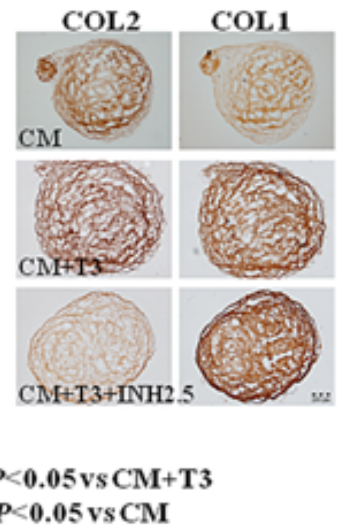

Figure 4. Role of SRC2, a steroid co-receptor of T3, on chondrogenesis of mesenchymal stem cells (MSCs) from human umbilical cord human stroma in spheroid cultures. (A) $S R C 2$ gene expression by real time quantitative reverse transcriptase polymerase chain reaction (qRT-PCR) in human chondrocytes from healthy donors $(\mathrm{CH})$, human cartilage from healthy donors (CART), human undifferentiated MSCs (UC MSCs 0D), and spheroids containing MSCs after 14 days in chondrogenic medium (CM) (UC MSCs14D). (B) Ratio COL2A1/COL1A1 gene expressions in spheroids containing MSCs cultured in chondrogenic medium (CM), CM plus $2.5 \mu \mathrm{M}$ (INH2.5), $10 \mu \mathrm{M}$ (INH 10), or $20 \mu \mathrm{M}$ (INH 20) of the inhibitor of the T3 steroid co-receptor ML151 respectively by real time quantitative reverse transcriptase polymerase chain reaction (qRT-PCR). (C) Representative images of immunohistochemistry tissue sections with antibodies against human collagen type II (COL2) and collagen type I (COL1) protein in spheroids containing MSCs cultured in chondrogenic medium (CM), $\mathrm{CM}$ plus $100 \mathrm{ng} / \mathrm{ml}$ of 3, 3', 5-triiodo-L-thyronine $(\mathrm{CM}+\mathrm{T} 3), \mathrm{CM}$ plus $100 \mathrm{ng} / \mathrm{ml}$ of 3, 3', 5-triiodo-L-thyronine plus $2.5 \mu \mathrm{M}$ of ML151 (CM+T3+ INH 2.5). All images have the same magnification (bar $=200 \mu \mathrm{m})$. (D) Ratio of COL2/COL1 protein obtained from densitometry study from spheroids cultured in chondrogenic medium (CM), CM plus $100 \mathrm{ng} / \mathrm{ml}$ of 3, 3', 5-triiodo-L-thyronine (CM + T3), CM plus $100 \mathrm{ng} / \mathrm{ml}$ of 3, 3', 5-triiodo-L-thyronine plus $2.5 \mu \mathrm{M}$ of ML151 $(\mathrm{CM}+\mathrm{T} 3+\mathrm{INH} 2.5) .{ }^{*} P<0.05$ versus $\mathrm{CM}+\mathrm{T} 3$ and ${ }^{\#} P<0.05$ versus $\mathrm{CM}$ by Mann-Whitney- $U$ test. 
A study of hypertrophy in our model was made immunohistochemistry analysis to measure the staining of MMP-13, COLX, and ALP proteins (Fig. 5A and C) and the expression of their genes by qRT-PCR (Fig. 5B), including the study of expression of transcription factors Runx2 like a hypertrophy marker and Sox9 like a chondrogenic marker. Staining for MMP-13 was decreased significantly only when ML151 was added to the medium plus T3 $(P<0.05)$. Although, similar results were found in the qRT-PCR studies of the MMP-13 gene (Fig. 5B), the differences were not significant. COLX stain levels were significantly $(P<0.05)$ decreased in the spheroids cultured in CM when T3 was added to the medium from the levels in spheroids grown in CM. Compared to spheroids cultured in CM plus T3, the addition of ML151 significantly $(P<0.05)$ increased staining for COLX. Expression of Runx2 was increased when inhibitor ML151 was in the medium but was not statistically significant. However, the expression of Sox 9 was statistically significant $(P<0.05)$ reduced when the inhibitor was in the medium (Fig. 5B). It is shown representative pictures with positive controls of all antibodies used in immunohistochemistry analysis and also the positive control of stain for Safranin O (Fig. 5D).
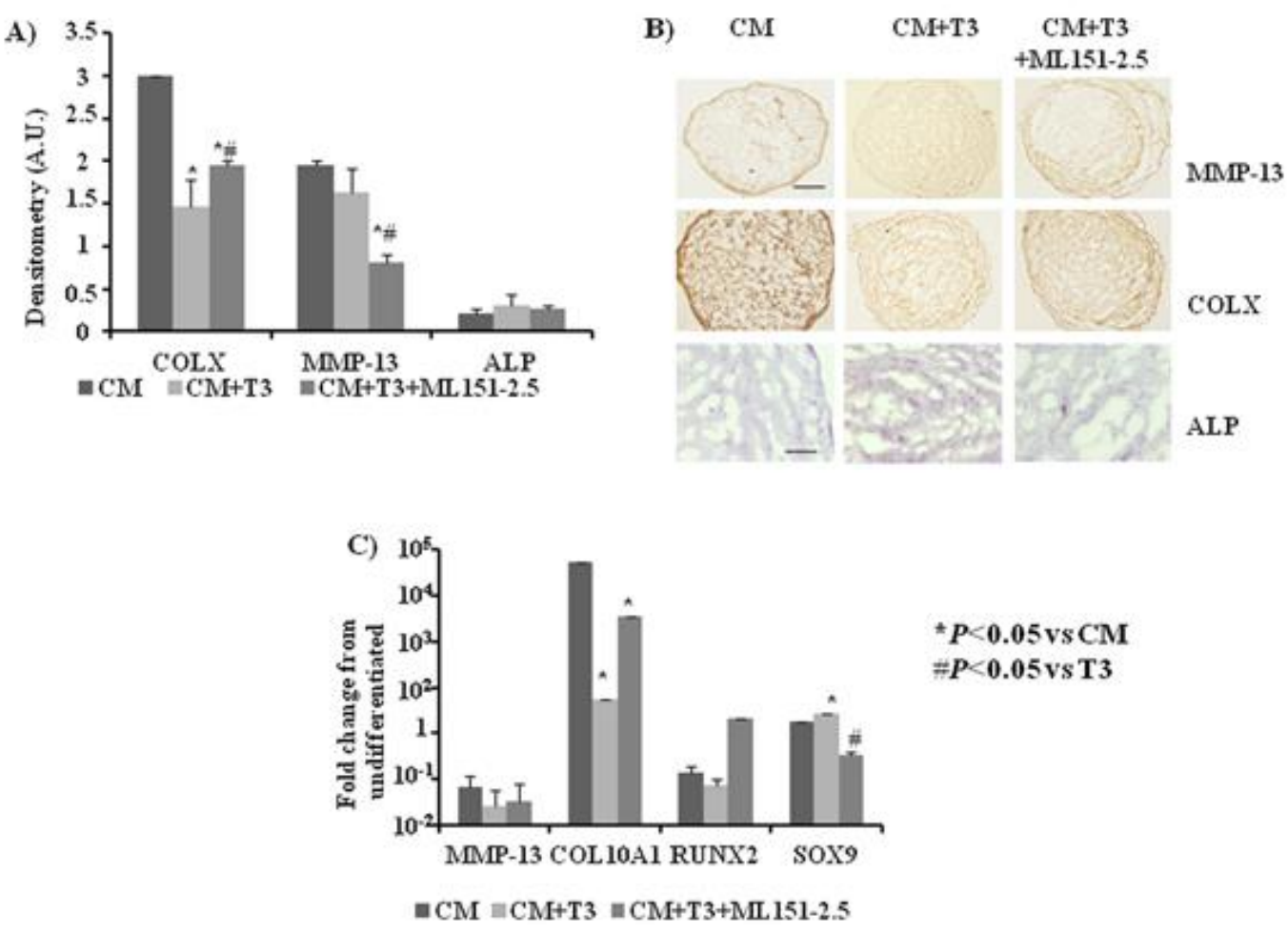

Figure 5. 3, 3', 5-triiodo-L-thyronine effects on hypertrophy in a chondrogenesis model using spheroid cultures of human umbilical cord mesenchymal stem cells (MSCs). (A) Densitometry study of human matrix metalloproteinase-13 (MMP13), collagen type 10 (COLX), and alkaline phosphatase (ALP) immunohistochemistry staining obtained from slices of spheroids containing MSCs cultured in chondrogenic medium (CM), CM plus $100 \mathrm{ng} / \mathrm{ml}$ of 3, 3', 5-triiodo-L-thyronine (T3), and CM plus $100 \mathrm{ng} / \mathrm{ml}$ of 3, 3', 5-triiodo-L-thyronine plus $2.5 \mathrm{ng} / \mathrm{ml}$ of ML151 (Inh). (B) Representative images of tissue sections of spheroids containing MSCs immunostained with antibodies against MMP-13, COLX, and ALP cultured in chondrogenic medium (CM), CM plus $100 \mathrm{ng} / \mathrm{ml}$ of 3, 3', 5-triiodo-L-thyronine (CM + T3), or CM plus $100 \mathrm{ng} / \mathrm{ml}$ of 3, 3', 5-triiodo-L-thyronine plus $2.5 \mu \mathrm{M}$ of ML151 (CM + T3 + Inh2.5). (C) MMP-13,COL10A1, and ALP gene expressions of spheroids containing MSCs cultured in chondrogenic medium (CM), plus $100 \mathrm{ng} / \mathrm{ml}$ of 3, 3', 5-triiodo-L-thyronine (T3), and CM plus $100 \mathrm{ng} / \mathrm{ml}$ of 3, 3', 5-triiodo-L-thyronine plus $2.5 \mathrm{ng} / \mathrm{ml}$ of ML151 (Inh) by real time quantitative reverse transcriptase polymerase chain reaction (qRT-PCR). $* P<0.05$ versus $\mathrm{CM}$; $\# P<0.05$ versus $\mathrm{CM}+\mathrm{T} 3$ by Mann-Whitney- $U$ test. 
The behavior of the Wnt family was studied by qRT-PCR and immunoblotting analysis in our chondrogenesis model. $\beta$-catenin, Frizzled, and GSK3- $\beta$ gene expressions were increased when T3 was present in the chondrogenic medium, all of them were statistically significant $(P<0.05)$. When ML151 was added to the medium, the $\beta$-catenin gene expression was statistically significant $(P<0.05)$ decreased versus its expression in CM plus T3 (Fig. 6A). Western blot analysis of the proteins revealed that $\beta$-catenin, Frizzled, and GSK-3B were statistically significant $(P<0.05)$ increased in CM plus T3 compared to CM alone; their levels decreased when ML151 at $2.5 \mu \mathrm{M}$ was added to the CM plus T3 medium (Fig. 6B). $200 \mathrm{ng} / \mathrm{ml}$ of DKK-1 was added into CM resulting a reduction of $B$-catenin and Frizzled genes expressions and an increase $G S K$ - $3 B$ gene expression respect their expression in $\mathrm{CM}$ alone, however, these genes inverted their expression when T3 was present in the medium, founding statistically significant $(P<0.05)$ increased the levels of B-catenin and Frizzled gene expressions and statistically significant $(P<0.05)$ decreased $G S K$-3gene expression (Fig. 6C) with respect their expression into CM plus DKK. These results were validated by Western blotting for B-catenin (Fig. 6D) and also the chondrogenic process was evaluated by immunohistochemistry of COL2 into spheroids formed during 14 days into CM when DKK-1 was added with or without T3. These results indicated that less COL2 was produced by spheroid cultured into CM plus DKK than COL2 was produced by spheroid cultured into CM plus DKK plus T3 (Fig. 6E) and these results were corroborated by qRT-PCR analysis of COL2 A1 (Fig. 6F). 

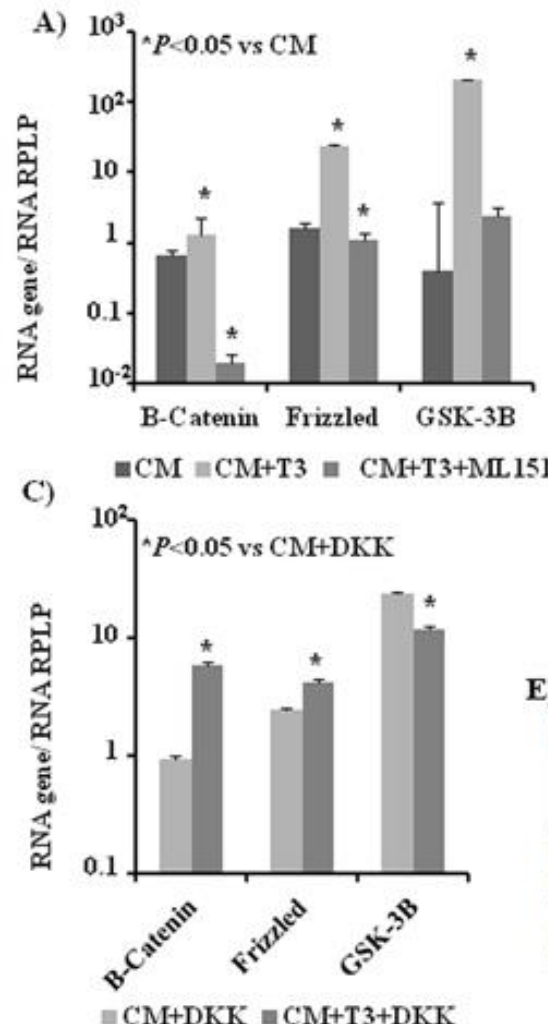

B) Size $\mathrm{CM} \quad \mathrm{CM}+\mathrm{T} 3 \quad \mathrm{CM}+\mathrm{T} 3+$

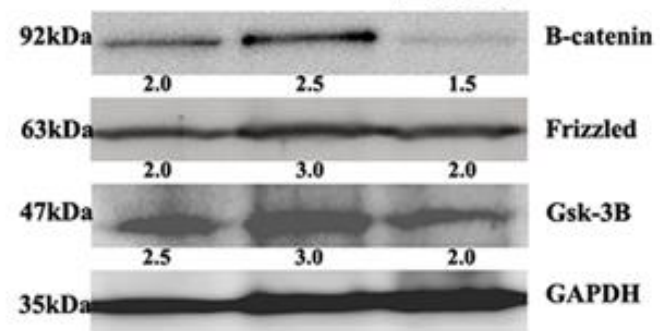

E)

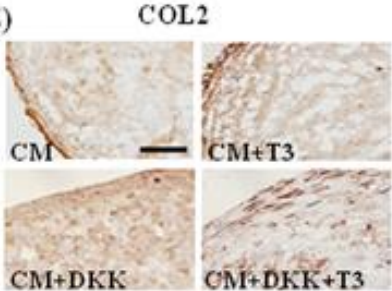

F) $10^{2}$

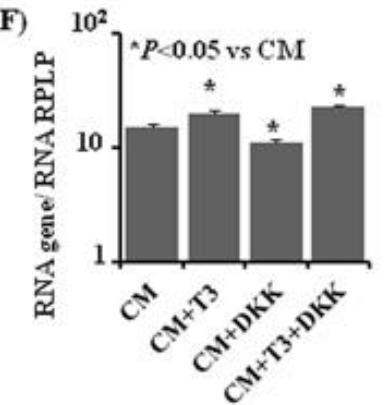

Figure 6. Wnt pathway in a chondrogenesis model using spheroid cultures of human umbilical cord mesenchymal stem cells (MSCs). (A) Real time quantitative reverse transcriptase polymerase chain reaction (qRT-PCR) of $\beta$-Catenin,

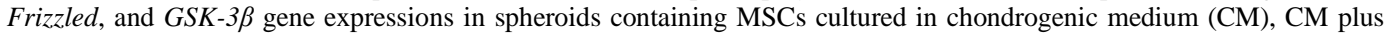
$100 \mathrm{ng} / \mathrm{ml}$ of 3, 3', 5-triiodo-L-thyronine (CM + T3) and CM plus $100 \mathrm{ng} / \mathrm{ml}$ of 3, 3', 5-triiodo-L-thyronine plus $2.5 \mathrm{ng} / \mathrm{ml}$ of ML151 $(\mathrm{CM}+\mathrm{T} 3+\mathrm{Inh}) .{ }^{*} P<0.05$ versus CM by Mann-Whitney- $U$ test. (B) Detection of $\beta$-catenin, Frizzled and GSK$3 \beta$ proteins by Western blot in spheroids containing MSCs cultured in chondrogenic medium (CM), CM plus $100 \mathrm{ng} / \mathrm{ml}$ of 3, 3', 5-triiodo-L-thyronine (CM+T3), or CM plus $100 \mathrm{ng} / \mathrm{ml}$ of 3, 3', 5-triiodo-L-thyronine plus $2.5 \mathrm{ng} / \mathrm{ml}$ of ML151 $(\mathrm{CM}+\mathrm{T} 3+\mathrm{INH} 2.5)$. Glyceraldehyde 3-phosphate dehydrogenase (GAPDH) or Tubulin were used as the control protein for western blots. (C) Real time quantitative reverse transcriptase polymerase chain reaction (qRT-PCR) of $\beta$-Catenin, Frizzled, and GSK-3 $\beta$ gene expressions in spheroids containing MSCs cultured in chondrogenic medium plus $200 \mathrm{ng} / \mathrm{ml}$ of DKK-1(CM + DKK), chondrogenic medium plus $100 \mathrm{ng} / \mathrm{ml}$ of 3, 3', 5-triiodo-L-thyronine plus $200 \mathrm{ng} / \mathrm{ml}$ of DKK-1 $(\mathrm{CM}+\mathrm{T} 3+\mathrm{DKK}) . \quad * P<0.05$ versus $\mathrm{CM}+\mathrm{DKK}$ by Mann-Whitney- $U$ test. (D) Representative images of immunohistochemistry tissue sections with antibody against human collagen type II (COL2) in spheroids containing MSCs cultured in chondrogenic medium $(\mathrm{CM})$, or CM plus $100 \mathrm{ng} / \mathrm{ml}$ of 3, 3', 5-triiodo-L-thyronine $(\mathrm{CM}+\mathrm{T} 3)$ or CM plus $200 \mathrm{ng} / \mathrm{ml}$ of DKK $(\mathrm{CM}+\mathrm{DKK})$ or $\mathrm{CM}$ plus $100 \mathrm{ng} / \mathrm{ml}$ of 3, 3', 5-triiodo-L-thyronine plus $200 \mathrm{ng} / \mathrm{ml} \mathrm{of} \mathrm{DKK}$ $(\mathrm{CM}+\mathrm{T} 3+\mathrm{DKK})$. All images have the same magnification (bar $=2 \mathrm{~mm})$. (E) Representative images of immunohistochemistry tissue sections with antibody against human collagen type 2 (COL2) in spheroids containing MSCs cultured in chondrogenic medium (CM), or CM plus $100 \mathrm{ng} / \mathrm{ml}$ of 3, 3', 5-triiodo-L-thyronine $(\mathrm{CM}+\mathrm{T} 3)$ or CM plus $200 \mathrm{ng} / \mathrm{ml}$ of DKK $(\mathrm{CM}+\mathrm{DKK})$ or CM plus $100 \mathrm{ng} / \mathrm{ml}$ of 3, 3', 5-triiodo-L-thyronine plus $200 \mathrm{ng} / \mathrm{ml} \mathrm{of} \mathrm{DKK}$ $(\mathrm{CM}+\mathrm{T} 3+\mathrm{DKK})$. All images have the same magnification (bar $=2 \mathrm{~mm})$. F) Real time quantitative reverse transcriptase polymerase chain reaction (qRT-PCR) of COL2Al gene expression in spheroids containing MSCs cultured in chondrogenic medium (CM), CM plus $100 \mathrm{ng} / \mathrm{ml}$ of 3, 3', 5-triiodo-L-thyronine $(\mathrm{CM}+\mathrm{T} 3), \mathrm{CM}$ plus $200 \mathrm{ng} / \mathrm{ml}$ of DKK $(\mathrm{CM}+\mathrm{DKK})$, and $\mathrm{CM}$ plus $100 \mathrm{ng} / \mathrm{ml}$ of 3, 3', 5-triiodo-L-thyronine plus $200 \mathrm{ng} / \mathrm{ml}$ of DKK $(\mathrm{CM}+\mathrm{T} 3+\mathrm{DKK})$. $* P<0.05$ versus $\mathrm{CM}$ by Mann-Whitney- $U$ test. 


\section{DISCUSSION}

Chondrocyte proliferation and differentiation are regulated by various endocrine, paracrine, and autocrine agents, including growth, thyroid and sex hormones, beta-catenin, bone morphogenetic proteins, insulin-like growth factor, iodothyronine deiodinase, leptin, nitric oxide, transforming growth factor- $\beta$, and vitamin D metabolites [Burdan et al., 2009]. Our group directed the differentiation of MSCs from human different tissues like synovial membrane toward chondrocyte-like cells testing different mediums and standard micromass conditions, that is, as pellets [Arufe et al., 2009, 2010], it was demonstrated that spheroid culture of MSC is a valuable method to direct differentiation towards chondrocyte-like cells, however, an optimum amount of aggrecan, the most important proteoglycan in the extracellular matrix of the joint cartilage, was not consistently achieved [Arufe et al., 2011a]. Characterization of MSCs from umbilical cord source by flow cytometry showed in the Figure 1A confirm previous results already published [Arufe et al., 2011b; De la Fuente et al., 2012; Kawata et al., 2012], indicating that our MSCs from human umbilical cord stroma present MSCs markers. Different dosages of T3 and PRL were added to chondrogenic medium to test their effect on chondrogenesis founding PRL had no effect on the chondrogenic process that could be found by qRT-PCR or immunohischemistry analyses. These results were in concordance with results published by Seriwatanachai et al. [2012] who provided evidence that the PRL increased endochondral bone growth and bone elongation, presumably by accelerating apoptosis of hypertrophic chondrocytes in the growth plate and/or subsequent chondrogenic matrix mineralization but not related with chondrogenesis onset. After performing dose-response experiments, qRT-PCR and immunohistochemistry results indicated that T3 at $100 \mathrm{ng} / \mathrm{ml}$ after 14 days in CM culture produced a significant increase in the expression of COL2 (Fig. 1B) and $A C A N$ genes and Safranin $\mathrm{O}$ staining over that found with chondrogenic medium alone (Fig. 2A-C). Boeloni et al. [2009] published dose-dependent results of T3 effect on the osteogenic differentiation using rat bone marrow mesenchymal stem cells and they regarded the conclusion that $1 \mathrm{pM} \mathrm{T3}$ dose resulted in greater collagen synthesis and alkaline phosphatase activity than greater dose like our work where $100 \mathrm{ng} / \mathrm{ml}$ of T3 is a bigger dose than $1 \mathrm{pM}$ but it keep being a physiological dose. We decided focusing all the experiments only at 14 days of differentiation like several recent published papers in the field [Perry et al., 2006; Weimer et al., 2007; Hardy et al., 2008]. The quality of our chondrogenic model was evaluated by RT-PCR checking genes related to chondrogenesis like AP2 $\alpha$, ITGa10, COL2, and AP2 $\epsilon$ [Camper et al., 2001; Freyria et al., 2009; Ronzière et al., 2010]. AP-2€ is involved in the regulation of ITGa10 transcription in chondrocytes [Wenke et al., 2006] and it is considered a hyperthrophic marker Niebler and Bosserhoff [2013] showed that AP-2 $€$ was increased during late chondrocyte differentiation, especially in hypertrophic chondrocytes. However, AP- $2 \alpha$ is expressed in the growth plate and in articular cartilage and has been described as a negative regulator of chondrocyte differentiation [Huang et al., 2004], maintaining cells in an early differentiate phenotype. We observed in our chondrogenic model that both factors are increased with T3 treatment but the AP- $2 \alpha$ increase is the biggest and this result might explain the chondrogenic action of T3 in our model as well as the statistically significant increase of COL2 and this fact might also explain we do not find hypertrophy in our model (Fig. 3A). The electronic microscopy analysis of our spheroids corroborated the increase of COL2 fibres in the gaps between cells (Fig. 3B-D).

We used ML151 to block SRC2 after confirming that SRC2 was present in our cells (Fig. 4A). Although, there were differences in the expression level of the SRC2 gene between the MSCs treated with different concentrations of inhibitor in the CM without T3 to eliminate possible interaction of this inhibitor on chondrogenesis by itself (Fig. 4B). The inhibitor probe molecule, ML151 (CID 5184800), blocked the TR $\beta$-SRC2 interaction. Mechanistic studies revealed that ML151 is a covalent inhibitor and binds irreversibly to Cys298 within the AF-2 cleft of TR $\beta$. This series will be useful for in vitro mechanistic studies of TR-SRC2 interactions, as well as other nuclear hormone receptor-co activator interactions [Johnson et al., 2011]. Our results indicated that $2.5 \mu \mathrm{M}$ of ML151 is enough to nullify the chondrogenesis increase achieved with T3, causing 
a significant decrease of COL2 and $A C A N$ gene expressions, compared to their levels in CM plus T3 (Fig. 4C-E).

Results of a previous study published by Mueller and Tuan [2008] supported the roles of T3 and TGF- $\beta$ in cartilage maturation; TGF- $\beta$ stimulated proliferation and suppressed hypertrophy, although T3 stimulated hypertrophy and apoptosis. On the opposite way, in our model the role of T3 seems to promote chondrogenesis with no hypertrophy, T3 treatment did not increase, even reduce MMP13, COLX, and ALP signal by immunohistochemistry analysis in spheroid after 14 days (Fig. 5A and B) as expected as referred by studies published by Mueller and Tuan [2008] and Liu et al. [2012]. Our results might be explained because of few days in culture and the source from our MSCs was different from used for those authors and the most important was that the T3 dose used in this work was physiological and very low in front of dose used for those authors.

It is possible that combination of TGF- $\beta$ withdrawal, a reduction in the level of dexamethasone, and the addition of T3 was essential for hypertrophy induction in the Muelleŕs work. Also Runx2 gene expression was evaluated by RT-PCR to check hypertrophy or increase of osteogenesis at genetic level as made Liu et al. [2012] in their paper and it was not hypertrophy increased in our work when T3 was added to CM (Fig. 5C). Jiang et al. [2008] used T3 to stimulate articular chondrocyte hypertrophy and mineralization in primary chondrocyte monolayer cultures over a long time period. However, the results obtained in our study indicate that T3, together with TGF- $\beta 3$, increased $A C A N$ expression in the extracellular matrix from chondrocytelike cells engineered from MSCs of human umbilical cord stroma in our chondrogenesis model as early as 14 days (Fig. 2). This does not contradict the possibility that hypertrophy may appear in our model over a longer time; this point was not addressed in this study at this time.

Wnt signalling pathways are the two most important signalling pathways that play key roles in embryonic development and in the biology of MSCs, including cell proliferation, differentiation, and epithelial-mesenchymal interaction [Sarkar et al., 2010; Centola et al., 2013; Baghaban Eslaminejad and Fallah, 2014]. Wnt signalling pathway represents two major channels of communication used by animal cells to control their identity and behavior during development. Hayward and Kalmar Arias [2008] reviewed the evidence for the relationship between Wnt signalling, which act as components of an integrated device that, rather than defining the fate of a cell, determines the probability that a cell would adopt that fate. Our results indicated that the presence of T3 in the chondrogenic medium increased gene expression and protein levels of $\beta$ catenin and Frizzled, as well as GSK-3 $\beta$ (Fig. 6A and B). These results agree with those published by Wang et al. [2007], who suggested that this accumulation of proteins could be resulted from a decrease in their degradation. Day et al. [2005] demonstrated that $\beta$-catenin was essential in determining whether mesenchymal progenitor cells would become osteoblasts or chondrocytes regardless of regional locations or ossification mechanisms. Similarly, our results seem to indicate that an increase of chondrogenesis produced by adding T3 in the chondrogenic medium would be mediated by $\beta$-catenin because of it was increased in the cells treated with T3 (Fig. 6A and B) as well as increased the COL2Al expression and COL2 in those cells (Fig. 1B and C). On the opposite way the decrease of $\beta$-catenin produced by ML151, which blocks SRC2 precluding the T3 actuation, also decreased the chodrogenesis process, as indicated by the decrease of COL2 production (Fig. 4C and D). However ML151 looks like be affecting expression of $\beta$-catenin independently of Frizzled and GSK-3B expression how demonstrate the results found by RT-PCR and Western blotting analysis (Fig. 6C and D). Dickkopf-related protein 1 (DKK-1) is a member of the Dkk protein family and an antagonist for Wnt signalling [Guerrero et al., 2014; Liu et al., 2014], which inhibits the translocation of $\beta$-catenin into the nucleus and its link on LRP5/6 component. Supplementation of Dkk-1 into CM plus T3 did not diminished levels of $\beta$-catenin in spheroid after 14 days because the expression of $\beta$-catenin increased comparing with $\mathrm{CM}$ alone plus Dkk-1 and this increasing was statistically significant $(P<0.05)$ by western blot analysis (Fig. $6 \mathrm{E}$ ), these results were corroborated by qRT-PCR and immunohistochemistry analysis (Fig. $6 C, D, F)$. Leijten et al. [2012] using human cartilage found similarly than we found into our in 
vitro analysis, where it looks like indicate that T3 is acting through SRC2 directly on $\beta$-catenin preventing the union of DKK-1 on LRP5/6 component.

\section{CONCLUSION}

$\mathrm{T} 3$, in a physiological amount, stimulates the chondrogenesis process without stimulating hypertrophy in an in vitro model using human MSCs; this effect is mediated through SRC2. T3 chondrogenic effect is modulated by Wnt pathway independently of LRP5/6 component. Overall our results present new possibilities for cellular plus hormonal treatments as therapeutic strategies for regeneration of tissues, including cartilage.

\section{ACKNOWLEDGMENTS}

The authors wish to thank Mrs. Purificación Filgueira Fernández and Mrs. Noa Goyanes and Mrs. María José Sánchez Dopico for technical support. This study was supported by a grant from Instituto de Salud Carlos III-Ministerio Economía y Competitividad N Expediente PI11/02799 Unión Europea-Fondo Europeo de Desarrollo Regional (FEDER) "Una manera de hacer Europa."

\section{REFERENCES}

Arufe MC, De la Fuente A, Fuentes-Boquete I, De Toro FJ, Blanco FJ. 2009. Differentiation of synovial CD$105(+)$ human mesenchymal stem cells into chondrocyte-like cells through spheroid formation. J Cell Biochem 108(1):145-155.

Arufe MC, De la Fuente A, Diaz S, Fuentes I, De Toro FJ, Blanco FJ. 2010. Chondrogenic potential of subpopulations of cells expressing mesenchymal stem cell markers derived from human synovial membranes. Osteoarthritis Cartilage 18:S80-S81.

Arufe MC, De la Fuente A, Fuentes I, Toro FJ, Blanco FJ. 2011a. Umbilical cord as a mesenchymal stem cell source for treating joint pathologies. World J Orthop 2(6):43-50.

Arufe MC, De la Fuente A, Mateos J, Fuentes I, De Toro FJ, Blanco FJ. 2011b. Analysis of the chondrogenic potential and secretome of mesenchymal stem cells derived from human umbilical cord stroma. Stem Cells Dev 20(7):1199-1212.

Baghaban Eslaminejad M, Fallah N. 2014. Small molecule-BIO accelerates and enhances marrow-derived mesenchymal stem cell in vitro chondrogenesis. Iran J Med Sci 39(2):107-116.

Boeloni JN, Ocarino NM, Melo AB, Silva JF, Castanheira P, Goes AM, Serakides R. 2009. Dose-dependent effects of triiodothyronine on the osteogenic differentiation of rat bone marrow mesenchymal stem cells. Horm Res 72(2):88-97.

Burdan F, Szumiło J, Korobowicz A, Farooquee R, Patel S, Patel A, Dave A, Szumiło M, Solecki M, Klepacz R, Dudka J. 2009. Morphology and physiology of the epiphyseal growth plate. Folia Histochem Cytobiol 47(1):5-16.

Camper L, Holmvall K, Wängnerud C, Aszódi A, Lundgren-Akerlund E. 2001. Distribution of the collagenbinding integrin alpha10beta1 during mouse development. Cell Tissue Res 306(1):107-116.

Centola M, Tonnarelli B, Schären S, Glaser N, Barbero A, Martin I. 2013. Priming 3D cultures of human mesenchymal stromal cells toward cartilage formation via developmental pathways. Stem Cells Dev 22(21):2849-2858.

Clément-Lacroix P, Ormandy C, Lepescheux L, Ammann P, Damotte D, Goffin V, Bouchard B, Amling M, Gaillard-Kelly M, Binart N, Baron R, Kelly PA. 1999. Osteoblasts are a new target for prolactin: Analysis of bone formation in prolactin receptor knockout mice. Endocrinology 140(1):96-105.

Darimont BD, Wagner RL, Apriletti JW, Stallcup MR, Kushner PJ, Baxter JD, Fletterick RJ, Yamamoto KR. 1998. Structure and specificity of nuclear receptor-coactivator interactions. Genes Dev 12(21):33433356.

Day TF, Guo X, Garrett-Beal L, Yang Y. 2005. Wnt/beta-catenin signaling in mesenchymal progenitors controls osteoblast and chondrocyte differentiation during vertebrate skeletogenesis. Dev Cell 8(5):739750 . 
De la Fuente A, Mateos J, Lesende-Rodríguez I, Calamia V, Fuentes-Boquete I, de Toro FJ, Arufe MC, Blanco FJ. 2012. Proteome analysis during chondrocyte differentiation in a new chondrogenesis model using human umbilical cord stroma mesenchymal stem cells. Mol Cell Proteomics 11(2):M111.010496.

Freyria AM, Ronzière MC, Cortial D, Galois L, Hartmann D, Herbage D, Mallein-Gerin F. 2009. Comparative phenotypic analysis of articular chondrocytes cultured within type I or type II collagen scaffolds. Tissue Eng Part A 15(6):1233-1245.

Guerrero F, Herencia C, Almadén Y, Martínez-Moreno JM, Montes de Oca A, Rodriguez-Ortiz ME, DiazTocados JM, Canalejo A, Florio M, López I, Richards WG, Rodriguez M, Aguilera-Tejero E, MuñozCastañeda JR. 2014. TGF-é prevents phosphate-induced osteogenesis through inhibition of BMP and Wnt/é-catenin pathways. PLoS ONE 9(2):e89179.

Hardy R, Rabbitt EH, Filer A, Emery P, Hewison M, Stewart PM, Gittoes NJ, Buckley CD, Raza K, Cooper MS. 2008. Local and systemic glucocorticoid metabolism in inflammatory arthritis. Ann Rheum Dis 67:1204-1210.

Hayward P, Kalmar Arias TAM. 2008. Wnt/Notch signalling and information processing during development. Development 135(3):411-424.

Huang Z, Xu H, Sandell L. 2004. Negative regulation of chondrocyte differentiation by transcription factor AP-2alpha. J Bone Miner Res 19(2):245-255.

Jiang J, Leong NL, Mung JC, Hidaka C, Lu HH. 2008. Interaction between zonal populations of articular chondrocytes suppresses chondrocyte mineralization and this process is mediated by PTHrP. Osteoarthritis Cartilage 16(1):70-82.

Johnson RL, Hwang JY, Arnold LA, Huang R, Wichterman J, Augustinaite I, Austin CP, Inglese J, Guy RK, Huang W. 2011. A quantitative high-throughput screen identifies novel inhibitors of the interaction of thyroid receptor beta with a peptide of steroid receptor coactivator 2. J Biomol Screen 16(6):618-627.

Kawata K, Kubota S, Eguchi T, Aoyama E, Moritani NH, Kondo S, Nishida T, Takigawa M. 2012. Role of LRP1 in transport of CCN2 protein in chondrocytes. J Cell Sci 125(Pt 12):2965-2972.

Leijten JC, Emons J, Sticht C, van Gool S, Decker E, Uitterlinden A, Rappold G, Hofman A, Rivadeneira F, Scherjon S, Wit JM, van Meurs J, van Blitterswijk CA, Karperien M. 2012. Gremlin 1, frizzled-related protein, and Dkk-1 are key regulators of human articular cartilage homeostasis. Arthritis Rheum 64(10):3302-3312.

Liu Y, Zhou J, Zhao W, Li X, Jiang R, Liu C, Guo FJ. 2012. XBP1S associates with RUNX2 and regulates chondrocyte hypertrophy. J Biol Chem 287(41):34500-34513.

Liu W, Konermann A, Guo T, Jäger A, Zhang L, Jin Y. 2014. Canonical Wnt signaling differently modulates osteogenic differentiation of mesenchymal stem cells derived from bone marrow and from periodontal ligament under inflammatory conditions. Biochim Biophys Acta 1840(3):1125-1134.

Livak KJ, Schmittgen TD. 2001. Analysis of relative gene expression data using real-time quantitative PCR and the 2(-Delta Delta C(T)) Method. Methods 25(4):402-408.

Lunstrum GP, Keene DR, Weksler NB, Cho YJ, Cornwall M, Horton WA. 1999. Chondrocyte differentiation in a rat mesenchymal cell line. J Histochem Cytochem 47(1):1-6.

Matsushime H, Quelle DE, Shurtleff SA, Shibuya M, Sherr CJ, Kato JY. 1994. D-type cyclin-dependent kinase activity in mammalian cells. Mol Cell Biol 14(3):2066-2076.

Moore JM, Galicia SJ, McReynolds AC, Nguyen NH, Scanlan TS, Guy RK. 2004. Quantitative proteomics of the thyroid hormone receptor-coregulator interactions. J Biol Chem 279(26):27584-27590.

Mueller MB, Tuan RS. 2008. Functional characterization of hypertrophy in chondrogenesis of human mesenchymal stem cells. Arthritis Rheum 58(5):1377-1388.

Niebler S, Bosserhoff AK. 2013. The transcription factor activating enhancer-binding protein epsilon (AP-2 $\epsilon$ ) regulates the core promoter of type II collagen (COL2A1). FEBS J 280(6):1397-1408.

Ogueta S, Muñoz J, Obregon E, Delgado-Baeza E, García-Ruiz JP. 2002. Prolactin is a component of the human synovial liquid and modulates the growth and chondrogenic differentiation of bone marrowderived mesenchymal stem cells. Mol Cell Endocrinol 190(1-2):51-63.

Park S, Kim E, Koh SE, Maeng S, Lee WD, Lim J, Shim I, Lee YJ. 2012. Dopaminergic differentiation of neural progenitors derived from placental mesenchymal stem cells in the brains of Parkinson's disease model rats and alleviation of asymmetric rotational behavior. Brain Res 1466:158-166.

Perry JJ, Yannone SM, Holden LG, Hitomi C, Asaithamby A, Han S, Cooper PK, Chen DJ, Tainer JA. 2006. WRN exonuclease structure and molecular mechanism imply an editing role in DNA end processing. Nat Struct Mol Biol 13:414-422.

Ronzière M, Perrier E, Mallein-Gerin F, Freyria A. 2010. Chondrogenic potential of bone marrow- and adipose tissue-derived adult human mesenchymal stem cells. Biomed Mater Eng 20(3):145-158.

Sarkar FH, Li Y, Wang Z, Kong D. 2010. The role of nutraceuticals in the regulation of Wnt and Hedgehog signaling in cancer. Cancer Metastasis Rev 29(3):383-394.

Seriwatanachai D, Krishnamra N, Charoenphandhu N. 2012. Chondroregulatory action of prolactin on proliferation and differentiation of mouse chondrogenic ATDC5 cells in 3-dimensional micromass cultures. Biochem Biophys Res Commun 420(1):108-113. 
Subramanian A, Fong CY, Biswas A, Bongso A. 2015. Comparative characterization of cells from the various compartments of the human umbilical cord shows that the Wharton's jelly compartment provides the best source of clinically utilizable mesenchymal stem cells. PLoS ONE 10(6):e0127992.

Suntornsaratoon P, Wongdee K, Goswami S, Krishnamra N, Charoenphandhu N. 2010a. Bone modeling in bromocriptine-treated pregnant and lactating rats: Possible osteoregulatory role of prolactin in lactation. Am J Physiol Endocrinol Metab 299(3):E426-E436.

Suntornsaratoon P, Wongdee K, Krishnamra N, Charoenphandhu N. 2010b. Femoral bone mineral density and bone mineral content in bromocriptine-treated pregnant and lactating rats. J Physiol Sci 60(1):1-8.

Suntornsaratoon P, Wongdee K, Krishnamra N, Charoenphandhu N. 2010c. Possible chondroregulatory role of prolactin on the tibial growth plate of lactating rats. Histochem Cell Biol 134(5):483-491.

Wang L, Shao YY, Ballock RT. 2007. Thyroid hormone interacts with the Wnt/beta-catenin signaling pathway in the terminal differentiation of growth plate chondrocytes. J Bone Miner Res 22(12):19881995.

Weimer JM, Benedict JW, Elshatory YM, Short DW, Ramirez-Montealegre D, Ryan DA, Alexander NA, Federoff HJ, Cooper JD, Pearce DA. 2007. Alterations in striatal dopamine catabolism precede loss of substantia nigra neurons in a mouse model of juvenile neuronal ceroid lipofuscinosis. Brain Res 1162:98 112.

Wenke AK, Rothhammer T, Moser M, Bosserhoff AK. 2006. Regulation of integrin alpha10 expression in chondrocytes by the transcription factors AP-2epsilon and Ets-1. Biochem Biophys Res Commun 345(1):495-501. 